http://dx.doi.org/10.18778/8088-538-7.15

\author{
DAWID MISZTAL \\ University of Łódź \\ Institute of Philosophy \\ TOMASZ SIECZKOWSKI \\ University of Łódź \\ Institute of Philosophy
}

\title{
ILL FARE THE HUMANITIES
}

\begin{abstract}
The starting point of our considerations is the two books published in 2010: "Ill Fares the Land" by the late Tony Judt and "Not for Profit" by Martha Nussbaum. The authors of both books share the conviction that neoliberal changes in the world of global capitalism radically impoverish culture and their consequences may be dramatic and irreversible.

In our paper we would like to emphasize the dangers to solidarity and social cohesion posed by neoliberal postulates. We also claim that promoting the neoliberal ideology in the context of higher education and institutions of civic society endangers the very democracy understood as reasonable pluralism (in John Rawls' terminology), consisting in rationality, plurality of opinions, lifestyles and conceptions of good, as well as consensus as the aim of social and political practices.
\end{abstract}

Keywords. Democracy, humanities, Nussbaum, Judt, neoliberalism.

\section{Introduction}

Many aspects of the modern day cultural sphere are lacking the dimension which only the humanities, philosophy amongst them, can supply. The so-called "war on terror" yields Islamophobia and feeds on it at the same time. Popular culture is getting more and more vague and unreflexive. The public sphere has been diminishing and, as Naomi Klein famously noted, multinational businesses has been taking over the spaces which used to be public. Scientific progress is geometrical but its moral assessment is impossible due to the lack of humanistic thought popular and important enough. The notion of common good, fundamental in creating a deliberative democracy, subdued to the notions of the private and the corporate. Political life, defined in terms of creating and realizing common goals, ideal as well as material, became the spectacle of factional calculation, governed by media coverage and opinion polls. The social and political interplay of values was replaced by a neoliberal, economic game played for sheer profit regardless of social or ecological costs. Homo sapiens was replaced by homo oeconomicus. And this is not a manifesto. These are the facts. 
All of which may or may not be deadly to Western democracies, time will tell. But what was always one of the strengths of liberal states was a well informed public opinion and powerful public sphere (in Habermas' sense) making communication between the government and the people possible and fruitful. For 200 years this public sphere has been constituted by independent media and intellectuals, creating a mirror which reflected the governing and the governed, formulated public goals achievable by means of rational policy, and controlled the exercising of power and bio-power by state officials. It would not, of course, be possible if not for the English and French Enlightenment, the French Revolution, the prolific idea of public education, and the massive growth of universities based - in continental Europe - on the Humboldtian model. The golden age of the public sphere must be located in the welfare states of post-war Europe, where governments formed after the massive war effort operated in the spirit of inclusion (of masses never before accounted for even by a democratic state) rather than exclusion and sheer administration. National health programmes (the NHS in Britain), social benefits, pensions and - in time - rights assigned to various groups of people (women, gays and so on), all of which struggled for decades to fully participate in public life, helped to build a powerful and audible public sphere, while respecting the subjectivity of those who constitute it.

But it was a long time ago. The financial crisis of recent years arose partly because of a gradual separating of the state from the individual in the context of an economic game, further undermining the idea of a welfare state, as deliberative democracy costs more than a mere neoliberal one. Funds were cut all the way with no group of interest left intact. For some it was a mere nuisance. For some it created a danger of extinction. The humanities, playing the first fiddle especially in the decades after the war, were among the first and most obvious victims of this neoliberal rant. It is what Terry Eagleton called recently "the slow death of the university". ${ }^{1}$ But perhaps what is endangering them is, at the same time, their biggest chance. The neoliberal paradigm, not only in economy, but also in anthropology and social sciences, was never so all-encompassing. But then were never so many cracks on its structure visible.

\section{Tony Judt and welfare state}

Diagnoses of something lost - or being lost - are not few. Among them there is a touching testament of the late Tony Judt, to which this paper owes its title. So what exactly has been lost, according to Judt? What are we missing now? The

1 Terry Eagleton, "The Slow Death of the University", The Chronicle of Higher Education, http://chronicle.com/article/The-Slow-Death-of-the/228991/, 16.05.2015. 
best way to answer these questions is to focus on what seems to be the main interest of his book. And that would be the role of the state and our contemporary attitude towards the state - its responsibilities, its problems, etc. Judt addresses these issues by presenting a kind of historical outline of crucial changes in the functioning of the state in post-war Europe or, broadly speaking, the post-war western world. This period, he claims, can be roughly divided in two parts [JUDT 2010, 20]. First, from the end of World War II to the late 60's we can observe the development of a welfare state. Apparently, as Judt indicates, we owe it to historical context, that both social-democratic and conservative governments of that time pursued a policy of social solidarity, and were aiming at reducing social inequalities (especially those of material, economical kind) as well as activating groups of exclusion (be they unemployed, illiterate, etc.) [JUDT 2010, 43]. This seems to be in accordance with some of Foucault's analyses, in which he claims that throughout post-war Europe economic policy was governed by a set of generally accepted imperatives, such as "reconstruction, planning, and, broadly speaking, socialization and social objectives - all of which entailed an interventionist policy on the allocation of resources, price stability, level of savings, the choice of investments, and a policy of full employment [FOUCAULT 2008, 98-99]. Pursuing such policy was possible on the premises that the obligations of the state are not only economical. Even if it was not a common or commonly expressed belief, the background of almost all political action of that period, as Judt argues, was the conviction that the understanding of the functioning of the state should not be reduced to its economic efficiency. According to this belief, the institution of the state should be conceived, first of all, as ethically responsible for its citizens. Hence, it is perfectly comprehensible and justifiable that a state has a right to intervene whenever the wellbeing of its citizens seems to be at risk - and this risk may be caused by natural and - what's more important - by economic factors as well [JUDT 2010, 62] (which simply means some form of state control over an otherwise free market). Moreover, the state is obliged to secure the wellbeing of its citizens by means of free education, public healthcare, and public transport.

However, in Judt's narrative, from the early 70's this model of understanding social policy starts to erode. The feeling of state-phobia - to use Foucault's expression - begins to manifest itself. Western societies became wealthier and wealthier, and members of those societies, feeling more socially secure and independent, began to perceive the political system in which they had been living, the political system that guaranteed such a strong, interventionist position of a state, as oppressive [JUDT 2010, 67-68]. And because of this they started to demand that the state step down, metaphorically speaking, from the chair of director of their lives (because that's exactly how they felt... they felt that their lives were being designed, directed and strictly controlled). This attitude was 
founded on at he belief that by violating freedom and basic rights of individuals (by means of interventionist policy for example), a state loses its legitimacy, not in a sense of losing its sovereignty, but in a sense of losing its right of representativity (it is no longer representative of its citizens) [FOUCAULT $2008,81]$. So paradoxically enough, the source of a welfare state's crisis (or one of its causes at least) was that at some point in time, from the perspective of its citizens, the welfare state seemed to care too much for them. ${ }^{2}$

For Judt, this mental atmosphere is best epitomized by the student riots of 1968 and the so called sexual revolution of the same year. Both should be understood as manifestations of change of priorities and self-interpretation tools: being a member of a community was gradually replaced as a fundamental element of individual identity by individual freedom [JUDT 2010, 70]. Soon enough this change and its "widespread assertion that "the personal is political" found its more theoretical expressions, which transformed postulates of revolting youth into a fully developed critique of a welfare state. This criticism was labeled neoliberal theory and was further elaborated through the whole decade of the 70 's. Proponents of this theory advocated for a radical restriction of the state's involvement or engagement in public life and economy, which was tantamount to market deregulation and social welfare limitation demands. Judt indicates that one of the fundamental presumptions of this stance is a kind of fetishization of economic growth, since neoliberal thinkers are usually deeply convinced that the growth of the economy is the main (if not the only) category that should be used to estimate the level of development of a country or a nation. Moreover, they conceive growth as a sufficient condition for providing a society with all the goods and social services formerly guaranteed by the state, which simply means that we should not bother ourselves with issues like the redistribution of goods, social equality, securing the stability of democracy or the quality of race and gender relations, as long as we commit ourselves to the pursuit of economic growth. And this conviction appears to be controversial (to say the least), since almost all of the cases of privatization or taking over selected functions of the state (like healthcare, transport, education) prove that after privatization none of those institutions function significantly better - quite the opposite, the priority of economic efficiency forces the policy of cutting costs (which always means reducing the quality of services) and eventually applying for public subventions (which seems to be particularly compromising for neoliberal theory) [JUDT 2010, 84-85].

\footnotetext{
${ }^{2}$ In opposition to Judt's reconstruction, Foucault locates the sources of this belief as far back as the late 40's and views what he calls state-phobia as the ever present (at least from the $18^{\text {th }}$ century, when it was expressed as a criticism of despotism and tyranny) undercurrent of a political dimension [FOUCAULT 2008, 76].
} 
Nevertheless, from the beginning of the 80 's, neoliberal theory becomes the predominant political stance, contributing - as a consequence - to the constant weakening of the role of the state in the lives of modern, western societies, which eventually resulted in dismantling of the welfare state. Thus, answering the initial question, according to Judt, we have lost the welfare state or - to be more precise - the idea of a welfare state as a viable political option. This answer, however, is incomplete, since it is missing a very important element of Judt's argument. For his reconstruction of the process of change in our understanding of the state's functioning is not limited to the political dimension only. In other words, abandoning the idea of a welfare state and adopting neoliberal theory as a foundation or a handbook of our political practice entailed changes not only on the political level, but also changes in the members of western societies, i.e. changes in ourselves. Judt claims that this shift from one political and economic model to another was accompanied by a kind of anthropological shift as well. And he does not mean any elaborated anthropological idea here. What he has in mind is rather the common, privileged way we are taught to interpret ourselves, understand who we are. The way which, supported by hegemonic position of neoliberal thinking, in a sense became natural, instinctive for us. We all consider ourselves to be rational, and by rational we mean that our actions aim at maximizing utility and economic profit. So we consider far more important an argument for or against any legislative act (or almost anything else for that matter) if it's an evaluation of costs this act will generate, than an attempt to reflect on its fairness [JUDT 2010, 11]. "We know what things cost but have no idea what they are worth", as Judt states, and what he is trying to say here is that in our own eyes (or in our own actions at least) each one of us became homo oeconomicus, everyone defines her or his rationality the way neoliberal theory tells us. This is the privileged way of self-understanding in our times.

Obviously, the concept of homo oeconomicus is not a novelty. What is new and unprecedented, however, is the strength and the depth of the way those anthropological premises and their consequences are rooted in contemporary consciousness. We consider this concept simply as an accurate description of the natural state of our human condition. Judt points out this fact, observing that as far as our preferable vision of the state is considered, "we seem unable to conceive of alternatives" [JUDT 2010, 11], despite the overwhelming impression that there is something wrong in the way the state actually functions. In other words, the problem is that neoliberal theory became not only the predominant political stance of our times (that would mean that we are still able to see other options and conceive them as theoretically equally viable and possible) - it became the way of our thinking about the state and about us as its citizens, about what's possible and even natural as far as the functioning of the state and human live are considered. Or, as Žižek puts it in his Pervert's Guide 
to Ideology (the film from 2012, directed by Sophie Fiennes and staring Žižek himself), the neoliberal vision of the state gained the status of integral part of reality, of what is real for us. And so he postulates that we should learn to be realistic once again by means of demanding what seems economically impossible.

Thus, we have lost not only the idea of a welfare state - we have lost something of ourselves. We have lost possibility to reflect on our rationality (we simply apply one of its possible definitions instead because we consider it to be our one and only possible and natural way of being rational). We have lost any quality of life that is not materialistic and selfish or needs an explanation or justification other than an economic one. We think what Judt is trying to say is that we have lost some part of our humanity. And what we are trying to say is that now, as a consequence, we are facing possibility of humanities being lost.

\section{The Troubled Humanities}

To justify this concern, let us begin with a simple and brief listing of the anthropological premises of neoliberal thinking and some of their political consequences, the way Judt seems to see them. Then we will consider their possible impact on humanities.

So, according to Judt, these are the most significant and dangerous results of the processes he analyzes in his "Ill Fares the Land":

- man is mainly (if not only) homo oeconomicus and thus all his rights are eventually reduced to economic rights: gaining profit, the pursuit of economic growth and material self-interest - these are the highest steps of our axiology, both social and personal.

- The removal of common, political perspective and erosion of the sense of community in its other than economic aspects.

- all of the world and every aspect of human experience can be (and actually is) described as a commodity, including education, healthcare.

- choosing between different kinds or visions of states has been replaced by choosing between the state and the market, with the latter being privileged.

- public debate (or what is left of it) is economically and not ethically informed.

Now, what is specific to the humanities, among many other things, is their critical and speculative approach. This approach requires the development of a certain ability to think critically and to reflect on various problems and issues, 
which also presupposes the capability of viewing them from many different perspectives. Why should we value and promote this approach? Because it is the best (if not the only) way of understanding human life in all its complexity: it opens one up to having concern for the lives of others; it helps one to imagine, feel and understand other people's situation, feelings, and beliefs; it renders one more immune to any attempts at manipulation; it enables one to have a fully human life [NUSSBAUM 2010, 7].

However, if we are indoctrinated to interpret ourselves as homo oeconomicus, we are automatically inclined to ask whether such an approach, and the development of abilities it requires, is profitable in an economic sense. We don't see this inclination as one of the possible perspectives, because - as Judt and Žižek argued - we are compelled and used to think of it as a part of our natural way of seeing things. So one of the first, important and extremely dangerous problems for the humanities is this demand to be economically profitable. And this prevalent demand is all the more perilous, since it manifests itself in many different forms. First of all, it serves as a choice criterion for young people deciding the best future career for them, and owing to the fact that they are making such decisions under the dictate of pursuit of economic growth, they reject the humanities as simply unprofitable and inefficient. They really do not need the ability to think critically and to view a variety of issues from many angles, for in a world where development or advancement is defined solely in terms of economic growth, all they need are really basic skills: literacy, numeracy, and, in some cases, more refined IT skills [NUSSBAUM 2010, 19]. The humanities appear to be completely useless and unnecessary.

On the other hand, this requirement of profitability shows itself as an institutional expectation of economic efficiency. Hence, the Polish Ministry of Science and Higher Education, as well as its equivalents all over the world, is consistently pursuing a policy of cutting costs. As a result, humanistic faculties are being shut down, there are fewer university courses due to the new, limits on higher students, and young talented people have no chance for an academic career, since universities are not interested in giving them jobs, because they simply cannot afford it.

Economic efficiency means not only that humanistic faculties are forced to function with smaller budgets. It also means that they should make money. Thus, the requirement of the immediate, practical application of humanistic research became one of the newest obsessions of the governing institutions. This is particularly striking and puzzling at the same time, as it clearly exposes a lack of understanding of the ways humanities (and other sciences for that matter) function. Philosophical concepts or scientific theoretical explanations do not necessarily reveal the possibilities of their practical applications at the moment of their formulation or presentation. Just imagine Copernicus, for example, 
applying for a grant and filling in the form with the rubric "practical application of your studies" with the sentence "space travel".

The same can be said about so called parametrization, which is an instrument of control and supervision designed and implemented as a method of making universities more efficient. However, scholars obliged to fill in more and more inquiry forms and questionnaires, became more bureaucratic rather than more efficient. It simply does not work, since there is apparently no link between bureaucracy and more efficient scientific and academic studies: there is no one who became better lecturer and/or scientist thanks to filling in tons of these documents. Especially since parametrization clearly favors the quantity of texts and papers and not their quality.

Unfortunately, these actions affect scholars' work more deeply as they feel more and more often compelled to choose the subjects of their studies in a spirit of opportunism in order to secure financing of their research and to secure time for all the bureaucracy. It leads to giving up what is really interesting for them, although perhaps it is a bit risky when it comes to the results of studies, and choosing "safer" issues, in a sense that those issues will enable them to successfully apply for a grant.

The primacy of the homo oeconomicus mentality and the removal of a common, political perspective, as well as the erosion of community spirit in aspects other than economic ones are profoundly changing all the connections and interrelations that the humanities function within. The sense of realizing a common goal or a sense of working on the basis of some common values seems to be of less and less importance among the community of scholars. It is being replaced by a more individualistic attitude and self-interest. When the common good is perceived mainly as an economic category, being a member of a given community becomes merely an economic transaction. And obviously, it is true both for scholars and students as well. Thus, the interrelation between the two groups evolves from the teacher-disciple model to the salesman-client pattern. Especially when every aspect of the world and human experience is described as a commodity, and the humanities and humanistic education become a product that needs to be sold according to the rules of the free market. And that is exactly what we are compelled to do. We sell our product according to the market's demand. Our clients, however, do not demand the development of critical thinking, imagination, esthetical and ethical sensitivity. They demand more narrowly tailored education and that is what we are forced to supply.

This new context, in which the humanities strive to function, is characterized by the admiration for the unregulated market as the best field for fulfilling the ambitions of homo oeconomicus. It also means contempt for the public sector and disdain for humanistic education as a part of this sector. As a result, the 
humanities are marginalized as unimportant and inefficient. This tendency is further intensified by the fact that public debate, as Judt has it, is economically and not ethically informed. Therefore, the main and most welcomed actors of public debate, as we can observe it, are economy experts and political experts, preferably with a neoliberal mindset, and not scholars of the humanities, artists or writers, who could promote alternative sets of values. Despite the fact that predominant economic theories and their advocates proved to be wrong so many times during the last few decades, the media and public opinion still seem to have no doubt about their expertise. And why should they have any doubts, if there is not any other option, no other perspective visible or hearable.

\section{Is democracy in danger?}

Of course, it's not as if there was no debate about the issue. In fact, it's been going on for at least 65 years, and the beginning of the debate may be marked by the 1947 speech given by Dorothy Leigh Sayers in Oxford, entitled "The Lost Tools of Learning". But that was the golden age of the humanities, or rather its beginning. 40 years later the climate changed and there's another milestone, Allan Bloom's The Closing of the American Mind, a work much broader in scope, but concerned among other things with the twilight of the humanities and the degeneration of universities. Although Bloom's book met with much well deserved criticism $^{3}$ (from Martha C. Nussbaum amongst others) some of its tenets happened to be prophetic. The twilight of classical, humanistic education, based on "Big Books" comprising the cannon of human civilization came to being in modern, technocratic western democracies. Bloom's main concern was - unnecessary - the moral conventions and the consequences of an instrumental and liberal paradigm shift in education. But more important than those are the consequences of eradicating the humanities from universities and education based on humanistic values altogether. The changes in the education paradigm

\footnotetext{
${ }^{3}$ The main issue being it promoted an imagined rather than a real vision of the past with its elitist view of democracy. Hence Bloom's ranting on Rawls, whom he associated with the new and dangerous ideas of equality and distributive justice. Here's Bloom's infamous remark on Rawls showing the impassable differences between the two of them: "John Rawls is almost a parody of this tendency [of anti-discrimination thinking - DM \& TS], writing hundreds of pages to persuade men, and proposing a scheme of government that would force them not to despise anyone. In A Theory of Justice, he writes that the physicist or the poet should not look down on the man who spends his life counting blades of grass or performing any other frivolous or corrupt activity. [...] This folly means that men are not permitted to seek the natural human good and admire it when found, for such a discovery is coeval with the discovery of the bad and contempt for it. Instinct and intellect must be suppressed by education. The natural soul is to be replaced with an artificial one."
} [BLOOM 1987, 30]. 
and their consequences, predating the global economic crisis of 2008, are the main topic of the aforementioned Martha Nussbaum 2010 book entitled Not for Profit. Why Democracy Needs the Humanities. ${ }^{4}$ Nussbaum's insights will guide us through some points of the list of dangers faced by modern democracies.

However, as Frank Donoghue rightly points out, the antagonism between corporate America and the humanities and what they represent is not a new phenomenon, rather dating back to the beginning of $20^{\text {th }}$ century, when the interests of the great capitalists and humanistic values taught at universities collided. ${ }^{5}$ So we may concede that antagonisms between business and the humanities is a given, but lately it has taken a new and troubling form. The close association of national governments with corporations working on global markets pushed the line dividing markets and universities and, most of all, changed the traditional alliances. Whereas so far national governments were interested in supporting the humanities, seeing it as a natural ally in making up the democracy from the grassroots level up, the rapid growth of the global market and its neoliberal ideology situated nations in anew and uncomfortable position. On the one hand, the democratic governments were obliged by their voters and the political and cultural tradition to support university education with the humanities as a necessary if not central part of it. On the other hand, the pressure from the markets was tightening and most democracies complied with the ubiquitous ideology of profit. As Martha Nussbaum puts it:

Thirsty for national profit, nations, and their systems of education, are heedlessly discarding skills that are needed to keep democracies alive. If this trend continues, nations all over the world will soon be producing generations of useful machines, rather than complete citizens who can think for themselves, criticize tradition, and understand the significance of another person's sufferings and achievements. The future of the world's democracies hangs in the balance. [NUSSBAUM 2010,2]

2013's report of the American Academy of Arts \& Sciences, subtitled "The Humanities and Social Sciences for a vibrant, competitive, and secure nation" sounds similar if not identical:

The humanities and social sciences are not merely elective, nor are they elite or elitist. They go beyond the immediate and instrumental to help us understand the past and the future. They are necessary and they require our

\footnotetext{
4 The line of argument in this book can be described as a continuation and application to universities of the main ideas of her earlier work, Cultivating Humanity (1997).

${ }^{5}$ The great capitalists of the early twentieth century saw in America's universities a set of core values and a management style antithetical to their own. Not only did they attack higher education, but, perhaps more surprisingly, even a hundred years ago they had already forced academics onto the defensive." [DONOGHUE 2008, 2]
} 
support in challenging times as well as in times of prosperity. They are critical to our pursuit of life, liberty, and happiness, as described by our nation's founders. They are The Heart of the Matter. ${ }^{6}$ [THE HEART OF THE MATTER 2013, 13]

There are many aspects in which the role the humanities play is crucial for modern democracies and the wellbeing of their citizens. The latest - and well heard - appeals and manifestos voicing the defense of the humanities touch upon many issues central to the very organization and axiology of democracies. By no means do the questions mentioned below exhaust the subject. ${ }^{7}$ What we list here is, nevertheless, crucial in modern-day debates about the status of the humanities.

\section{Without the humanities there can be no reasonable pluralism which seems to be the conditio sine qua non of meaningful liberal democracy. There's} a widespread agreement in modern liberal states, that there is no democracy in the true sense without some kind of public rationality, be it Rawlsian public reason, a Habermasian idea of deliberative democracy or a Rortian conversation of mankind. The basic idea is that to create a society based on an ideology of neutrality and equality of chances, there has to be some kind of consensus between competing world-views and conceptions of good. This can be achieved only by means of the ideological neutrality of the state, as Jocelyn Maclure and Charles Taylor rightly point out [MACLURE, TAYLOR 2011, 13], establishing equality of all moral stances, be they religious or secular. But this neutrality, although a necessary condition of any rational pluralism, is not enough on its own. The functioning of modern democracies is dependent on the existence and health of the public sphere, as defined by Jürgen Habermas in The Structural Transformation of the Public Sphere ${ }^{8}$ [HABERMAS 1989]. For Habermas, the public sphere was "a social space-distinct from the state, the economy, and the family - in which individuals could engage each other as private citizens deliberating about the common good." [MENDIETA, VANANTWERPEN $2011,2]$. Of course, the main interest of Habermas was an ideal type of the bourgeois public sphere (bürgerliche Öffentlichkeit). But "we are all bourgeois

\footnotetext{
${ }^{6}$ One of the goals advanced by the report is described as educating "Americans in the knowledge, skills, and understanding they will need to thrive in a twenty-first-century democracy".

${ }^{7}$ In addition to being vital to core democratic values of human dignity and human development, the humanities serve as checks and balances to scientific progress. Without them it can go not only rogue and unethical, but supposedly also authoritarian (it is no coincidence, that all the great dystopias of modern day are basically the realities without books).

8 With minor modifications. As Mendieta and Van Atntwerpen point out, "Habermas paid insufficient attention to religion in this early work" (MENDIETA, VAN ANTWERPEN [2011], p. 3). The mistake was corrected later, with Habermas writing more and more on the topic of religion and its place within the modern democracy in a post secular fashion (see for instance HABERMAS [2002] and HABERMAS [2003]).
} 
now". Meaning, that what was elitist at its source (liberal instead of plebeian (HABERMAS [1989], p. xviii), in modern democratic societies is becoming more and more egalitarian. The chief component of this new socio-political invention was that the public sphere was mainly a space of reason-giving, of debating and arguing about the common good and the (also political) trajectories to pursue it. This realm, in turn, demands an informed public opinion or finds its rationale in it (HABERMAS [1989], pp. 89 and further) and that can come to being only by means of public education independent on material conditions of the citizens. Public debating the ways to pursue common goals or creating one's own ways of life isn't possible without this "political and cultural paideia" - learning to live and cooperate with others, but also learning the basic facts of cultural tradition, of acceptable methods of argumentation, of the advantages of political and social participation which leads straight to the main issue of creating one's own way of life and pursuing one's own conception of good. It's unnecessary to stress the role that a humanistic education ${ }^{9}$ plays in that understanding of a person's choices in the democratic reality. Certain patterns of fulfilled life can emerge only from the knowledge of past and present ways of life, of which only the humanities can sufficiently inform us.

Without the humanities there is no valuable life possible. Nussbaum's definition of democracy as a valuable and quality life encompasses, in a way, all of the most important modern-day concepts of democracy. First of all, there is the classical, political concept based on the premise that there is no real democracy without a politically informed public opinion able to make conscious political choices. Such a form of political community is impossible to maintain and reproduce without holistic humanistic education, recognizing competing world-views and following the consequences of one's actions. Secondly, we have the Habermasian/Rortian idea of deliberative democracy, democracy in a constant act, never going all the way and based on the idea of communication worked out by means of rational discussion. Here as well, only the humanities can supply the participants with the tools necessary to create an environment of a free and unconstrained debate. Thirdly, we have the Rawlsian idea of democracy based on the principles of justice and the concept of overlapping consensus (of comprehensive doctrines). Even if Rawls thought otherwise, stressing the necessity of pure rational calculation and its sufficiency for establishing a just and equal society, obviously there has to be a comprehension

\footnotetext{
${ }^{9}$ The noticeable diminishing of the public sphere is posing a danger to the very activity of the university, but at the same time it creates an opportunity of the universities to become the core institutions the future prosperity of democracy. As Michael Burawoy puts it, "the university has to be at the center of organizing public discussion about the direction of society. As the more conventional representatives of publics - trade unions, political parties, voluntary organizations, religious associations - are falling down on their public mission, the university has to take up its calling as the pivotal institution to orchestrate a deliberative democracy" (BURAWOY [2011]).
} 
of these doctrines if they are not to be excluded from the public sphere by force or otherwise. This comprehension in turn must be something more than quasiKantian, an intellectual act of recognizing the mathematical necessity of, say, the principles of justice, because it has to be rooted in a deeper understanding of others' needs, values and presuppositions. Contrary to Rawls' main idea from Theory of Justice, we need something more than just reason to follow in his footsteps. Tolerance and openness cannot be an effective intellectual stance without empathy and sympathy, and those two we can learn from philosophy, literature and sometimes even from religion. If we take these three components of modern-day democracies (informed public opinion, communication and socio-economic justice) together, we can see that they add up to the basis of Nussbaum's own conception of democracy as a quality life. But they are not enough. Modern democracies seem to adopt two approaches (paradigms) of development. The first is human-oriented, the second, growth-oriented (NUSSBAUM [2010], p. 16). The former stresses the role of holistic human development, the latter considers economic growth as the priority. Both have educational consequences: people educated according to the growth-oriented paradigm are more specialized, standardized, but altogether less empathic and more limited in their perception of the world and other cultures. It is impossible to sustain vital democracy based on market- and growth-oriented education. Not only does this model promote inequalities (in wealth as well as in education), but it is also antidemocratic in the strict sense, because it doesn't recognize "the inalienable human dignity" (NUSSBAUM [2010], p. 24) which must be the sole base of democracy according to Nussbaum's Human Development paradigm. There are things such as health, concern for other species, bodily integrity, emotions, senses and life itself, among other capabilities central to democratic citizenship (see NUSSBAUM [2000]). Some of them are biological, but some overtly cultural. Among the latter there are - in one form or another - abilities usually associated with the humanities and the arts: "the ability to think critically; the ability to transcend local loyalties and to approach world problems as a 'citizen of the world'; and, finally, the ability to imagine sympathetically the predicament of another person" (NUSSBAUM [2010], p. 7).

Without the humanities there is no multiculturalism, because there is no understanding of what is strange and alien. This lack of understanding is true of religious and political divisions, at which Habermas encourages us to take a look, but there is also supposedly the most important and pertaining question of broader cultural differences as the vast majority of modern democracies are, or are rapidly becoming, multicultural. While ethnically and religiously homogenic states have started to become a relic, this is not necessarily true about the ways of life of smaller social groups. Some of them still live in a kind of ideological ghetto, be it political, ethnic or religious. Rawls' idea of an overlapping consensus of comprehensive doctrines in a liberal state (see esp. RAWLS 
[1996], pp. 133-172) is certainly a noble if only regulative one. The idea demands not only the moral and religious neutrality of the state (relatively easy to achieve by constitutional means) but also self-regulation and self-control on the part of groups representing various conceptions of good. These selfconstraints can only partly be achieved by means of state control, because, by definition, the belief of the groups are beyond the reach of a democratic state, as they should be. The implication is that there has to be some kind of natural process by which various religious groups come to understand and respect one another.

It is often assumed that multiculturalism is an issue to be treated on the national level. But that is not the case: as Martha Nussbaum points out, multiculturalism has its roots not in the separate states, but in the very character of issues we must confront. And instead of being national, they have become "global in their scope" (NUSSBAUM [2010], p. 79). What we need, then, is not merely inactive tolerance, but rather a "global understanding" (NUSSBAUM [2010], pp. 8184 ), the teaching of world citizenship. Nussbaum claims that these humanistic sentiments necessary for fruitful cooperation instead of exploitation, can be fostered by education. "The world's schools, colleges and universities, therefore, have an important task: to cultivate in students the ability to see themselves as members of a heterogeneous nation (...) and a still more heterogeneous world, and to understand something of the history and character of the diverse groups that inhabit it" (NUSSBAUM [2010], p. 80).

Without the humanities there is no society of dialogue, because there is no understanding of the other - their distinctness, needs, desires and sufferings. Metaphysics aside, in the (post)secular realm of liberal democracies, the dialogical society is a goal to pursue, but the metaphysical means offered by Levinas and other philosophers of dialogue are deeply flawed. They relate to a certain type of sensitivity which is basically of a religious nature. Postindustrial, postmodern and post secular societies do not all share the religious and metaphysical approach which enabling a dialogical contact with the Other to be established, be it by looking in his or her eyes or otherwise. Empathy is a tool necessary for democracies (or civil societies) to flourish, but it is an ability impossible to teach. As it guarantees moral progress ("enlarging the circle of the 'we', enlarging the number of people whom we think of as 'one of us'", as Rorty cites Peter Singer) it can be only encouraged by the knowing of cultural tradition, books big or little, philosophical treatises, ingenious novels, breathtaking music pieces. And by direct contact with popular culture as well.

And to do that there is a necessity to change the nature or the definition of cultural goods from commodities to carriers of values. Democracy, then, needs citizens' understanding of various and diverse values, their cultural background and the necessity of a dialogue. Only the liberal arts can offer the education of 
openness towards the other, of empathy towards those who are in pain. Only the humanities, at the university level as well as in public discussions, can enhance this sense of empathy, by concentrating on different cultural patterns of understanding reality, religion and the political. And - without appealing to the wrath of gods or authorities - only they can stigmatize any form of suffering despite the differences between us and those who need our help and solidarity.

\section{Conclusion}

Democracy has its checks and balances. Chief among them is the role played by public intellectuals in liberal societies. But this role can be played effectively only insofar as intellectuals are grounded in truly public and informed opinion. Without humanities or with humanities sent to a sparse ghetto of several academic institutions, such an opinion is flawed and impaired. Promoting humanities not only at universities, but also at other levels of education and in polytechnics is in best interest of democracies in dangerous state of economic and demographic tribulations and diversity of world-views.

Judt and Nussbaum sound dramatic but not utterly pessimistic or catastrophic. There is much to do to stop the process of devaluating the humanities by national governments and multinational corporations alike, but then there is a lot going on. For a long time now the voice of humanistic intellectuals has not been this audible and the possibilities of social and political participation of citizens of modern-day democracies has never been this many. Manifestos, reports and debates are not enough but they are definitely a step in the right direction which, if followed, would restore the powers of the public and create a space for emphatic and responsible citizenry that most of the ideologues of democracy ever dreamt of.

\section{References}

BLOOM, A. [1987], The Closing of American Mind, New York: Simon \& Schuster.

BURAWOY, M. [2011], "Redefining the Public University: Developing an Analytical Framework, Transformations of the Public Sphere", http://publicsphere.ssrc.org/burawoyredefining-the-public-university/, (10.08.2013).

CABOT, L. W. [2013], The Heart of the Matter, American Academy of Arts \& Sciences, Cambridge, MA.

DONOGHUE, F. [2008], The Last Professors. The Twilight of the Humanities in the Corporate University, $3^{\text {rd }}$ ed., New York: Fordham University Press.

FOUCAULT, M. [2008], The Birth of Biopolitics. Lectures at Collège de France 1978-1979, New York: Palgrave MacMillan. 
HABERMAS, J. [1989], The Structural Transformation of the Public Sphere, Cambridge, MA: The MIT Press.

HABERMAS, J. [2002], Religion and Rationality, (ed.) Eduardo Mendieta, Cambridge: Polity Press.

HABERMAS, J. [2003], The Future of Human Nature, Cambridge: Polity Press.

JUDT, T. [2010], Ill Fares the Land, New York: The Penguin Press.

MACLURE, J. TAYLOR, C. [2011], Secularism and Freedom of Conscience, Cambridge, MA: Harvard University Press.

MENDIETA, E. VANANTWERPEN, J. [2011], "Introduction”, [in:] Judith Butler et al., The Power of Religion in the Public Sphere, New York: Columbia University Press, pp. 1-14.

NUSSBAUM, M. C. [1997], Cultivating Humanity: A Classical Defense of Reform in Liberal Education, Cambridge, MA: Cambridge University Press

NUSSBAUM, M. C. [2000], Women and Human Development: The Capabilities Approach, Cambridge MA: University Press, Cambridge.

NUSSBAUM, M. C. [2010], Not for Profit. Why Democracy Needs the Humanities, Princeton: Princeton University Press.

RAWLS, J. [1996], Political Liberalism, New York: Columbia University Press.

RORTY, R. [2010], An Ethics for Today, New York: Columbia University Press. 